\title{
DESIGN OF WATER NETWORK PIPE SYSTEM OF SPRINKLER IRRIGATION FOR MINIMUM COST \\ Hassan, A. A.
}

\begin{abstract}
To optimize the life-cycle cost of pressurized irrigation system, we must find the set of pipe sizes that gives the minimum sum of fixed plus operating costs. If a very small pipe sizes are used, fixed costs will be low, but the operating (power) cost of overcoming friction losses in the pipes will be relatively high. As the pipe diameters increase, the fixed cost will also increase. The optimum pipe sizes are that minimizes the sum of fixed plus the operating costs. A linear programming model was developed for the design of water network of a hand moved sprinkler system of 2 main lines supply 10 fields each contains a submain and two portable hand move sprinkler laterals. The system comprises junctions or nodes and pipe sections between adjacent nodes. The objective function is to minimize total cost subject to three groups of constraints. The first group concerned about pressure head at each node. The second were to limit the water velocity in the pipe sections between $1 \mathrm{~m} / \mathrm{s}$ to $2 \mathrm{~m} / \mathrm{s}$. The last, involves the non negativity of the various decision variables. The results showed that the minimum total annual cost to operate the system is 1135 L.E/year. fed. at $1.6 \mathrm{~m} / \mathrm{s}$ average water velocity in pipes. The head loss gradient was $1.9 \mathrm{~m} / 100 \mathrm{~m}$ and the total area was 110 feddan, The system operating time 1440 hour/season to add $3400 \mathrm{~mm} /$ season. The sprinkler discharge is $1.4 \mathrm{~m}^{3} / \mathrm{h}$ operate at 3 bar pressure head spaced $7 \mathrm{~m}$ by $7 \mathrm{~m}$. Linear programming method results were verified by two other methods, namely, water velocity and unit head loss (head loss gradient). Comparing results of the linear programming method with the other two methods showed faster and more accurate results, especially when applied by Microsoft EXCELL spreadsheet.
\end{abstract}

Senior Researcher at Agric. Rech. Center. 


\section{INTRODUCTION}

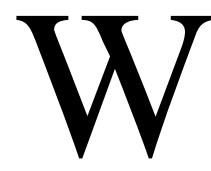

hen irrigation water is supplied by pump, the cost of the delivery system (main and submain pipeline) and the energy cost (cost of operation of the pumping station) are interrelated. When the diameter of the pipeline becomes smaller, the cost of the piping network is reduced but the energy cost is increased as a result of greater friction losses along the pipeline. The designer of an irrigation system should aim to determine an adequate size and length of the main and submain pipelines so that the total annual cost (fixed cost plus energy cost) is minimized. For optimal design of collective irrigation networks, various methods have been successfully developed and applied by Labye et al., 1988. Linear, nonlinear and dynamic programming methods applied by Theocharis et al. 2006; Planells et al., 2007. Keller and Bliesner (1990) noted that although the selection of economical pipe sizes is an important engineering decision, it is often given insufficient attention, especially in simple irrigation systems. In such projects, simple tapered submain lines or simple branched networks is useful. Many designers use very simple methods, including unit head loss (setting a limit on the head loss per unit length), limiting velocity, and percent head loss (setting a limit on the friction head loss in the main line networks). Various methods have been proposed to address the question of optimal design of simple irrigation delivery systems. Keller (1975) proposed a method based on the construction of economic pipe selection charts for determining the most economical pipe diameters in tapered submain lines or in a simple branched network. This method, as Keller and Bliesner (1990) demonstrated, resulted in designs which were less expensive than the previously mentioned simple methods. On the other hand, several analytical techniques (Sharaf., 1996, Valiantzas, 2003) and computer aided design techniques (Bralts and Segerlind, 1985; Bralts et al., 1993; Kang and Nishiyama,1996a, b; Ismail et. al., 2001) have been proposed, which focus on the optimization of single diameter pipeline networks. These methods are usually based on hydraulic criteria alone and ignore economic criteria. In this paper, two simple analytical methods are presented beside linear programming model for calculating adequate pipe diameters along an irrigation delivery system, contains main and submain 
lines to get the minimum total annual cost. For the estimation of the friction losses the Hazen - Williams's equation, was used. The methods applied do not need the use of graphs or tables and they can be used for the design of a simple pipeline or small irrigation network with outlets of various nominal discharges and pressure heads, sections of various lengths of PVC pipes, and for horizontal and uniform slope. All the methods applied by Excel spread sheet.

\section{Optimization Model Development:}

Designing an economic sprinkler irrigation system, particularly over a large area, can be a tedious and time consuming. Several models will be applied; one of them used to design economic system is linear programming model. The model described in this paper Shown in Fig. (1) assumed that the layout of the field, as well as the discharge loads have already been determined. It is also assumed that the water is supplied from the regional main water source which could provide variable pressure head. A pipe network comprises junctions or nodes, and pipe sections between adjacent nodes. For example, in system layout shown in Fig. (1), there are $i$ nodes $(i=1,2,3 \ldots 13)$ and $j$ pipe sections $j=1,2,3$ ....13. each pipe section is assigned the same number as the node downstream. For example, the pipe section upstream from node 7 is assigned as -7- .

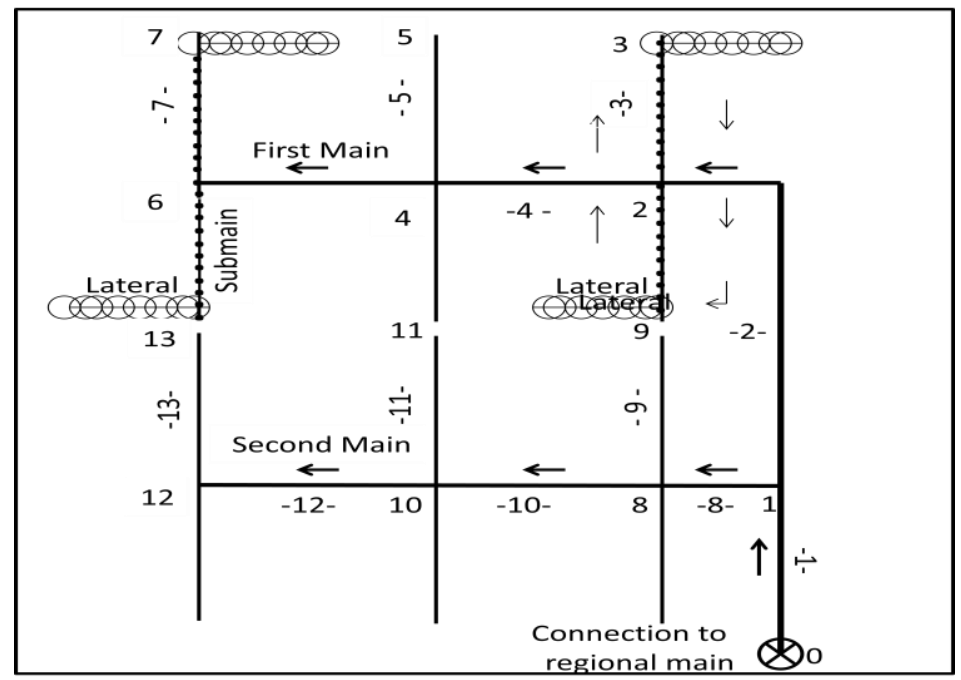

Fig. (1) Scheme of sprinkler irrigation pipe network 
The pressure head hu(i) required at the inlet to the laterals $3,5,7$.. 13 nodes are computed as:

$$
h u(i)=h s+\frac{3}{4} h f_{l}+h r \pm \frac{\Delta z}{2}
$$

Where:

$h u(i) \quad$ Pressure head required at the lateral inlet $(\mathrm{m})$

hs Pressure head to operate the sprinkler (m)

$h f_{l} \quad$ Pressure head loss in lateral pipe (m)

$h r \quad$ Riser height (m)

$\Delta z \quad$ Elevation difference along the lateral.

The total head at the lateral inlet $\mathrm{Hu}(\mathrm{i})$ is determined by adding the surface elevation $\mathrm{z}(\mathrm{i})$ and the local head loss $\mathrm{k}$ in the take off, then:

$$
H u(i)=h u(i)+z(i)+k
$$

The pressure head at each lateral inlet should be at least $H u(i)$ which considered the first constraint, this expressed mathematical as:

$$
H o \pm Z o-\sum_{j=1}^{j=m} H f(j) \geq H u(i) \pm Z(i)
$$

Where:

Ho Net available head at pump

Zo Elevation head at the water source + for upward, - for downward.

$\Sigma H f(j) \quad$ Sum of head losses from regional main along the path of flow to each section $(j)$

$H u(i)$ total pressure head at lateral inlet, node (i)

$Z$ (i) elevation head at lateral inlet, node (i)

When a pump supplies the irrigation water, Ho is a variable having predetermined value. For this purpose an assumption considered average velocity of water inside the pipe sections is $1.5 \mathrm{~m} / \mathrm{s}$. to get initial value of Ho. The head loss due to friction $\mathrm{hf}(\mathrm{j})$ along length, $\mathrm{L}(\mathrm{j})$ when the discharge $\mathrm{Q}(\mathrm{j})$ and diameter, $\mathrm{D}(\mathrm{j})$ were computed by Hazen-Williams formulas considering the friction factor $\mathrm{C}=150$, as: 


$$
h f(j)=\frac{1.22 * 10^{10}\left(\frac{Q(j)}{3.6 * C}\right)^{1.852} * L(j)}{D(j .)^{4.87}}
$$

The total head loss HF along the system pipe sections is determined by summing the partial head loss along the different sections. The configuration of the conveyance piping system within the field (main, submain and laterals) is fixed. However, the model can be easily applied to any size and dimensions of field. For initial estimate of available pressure head $\mathrm{Ho}$ at the water source, the water velocity inside the system pipe sections was considered $1.5 \mathrm{~m} / \mathrm{s}$.

\section{The objective function:}

The objective function is to minimize the total annual cost (TAC) of sprinkler irrigation system under certain limitations called constraints, expressed mathematically by:

\section{mimize $T A C$}

\section{Pipes cost:}

The cost per unit length for pipe with diameters $D(j)$ is $c(j)$, the cost along $\mathrm{L}(\mathrm{j})$ is:

$$
C(j)=c(j) \times L(j)
$$

The prices and specifications of the PVC pipe scheduled 80 (according to USplastic .com) ranged from 1.5 to 12 inch were presented in Table. (1). The relationships between the prices and diameters were found to be power function with high correlation as 0.995 on the following form:

$$
C(j)=8.8 c_{1} D(j)^{C_{2}}
$$

Where:

$\mathrm{C}(\mathrm{j})$ PVC pipe price for pipe length of section $\mathrm{j}(\$ / \mathrm{m})$

$\mathrm{C}_{1.2}$ The coefficients of the power function

$\mathrm{D}(\mathrm{j})$ Pipe diameter for section $\mathrm{j}(\mathrm{mm})$

8.8 Official price of one dollar in the Egyptian market in that time.

Regression analysis of available PVC pipes of January 2016, leads to average value of $C_{1}$ as 0.0055 and $C_{2}$ as 1.723 at that time. 
The capital cost of pipes $C C_{\text {pipe }}$ is determined by summing the partial costs of the $m$ pipe sections as,

$$
C C_{\text {pipe }}=\sum_{j=1}^{m} C(j)
$$

\section{Energy cost:}

The annual energy requirement for an irrigation delivery system depends on annual irrigation requirements and the power needed to pump the water. The total power required for the pump providing the water in the system can be expressed as:

$$
p=\frac{Q H}{0.036 \quad \eta_{T}}
$$

Where:

$\mathrm{P} \quad$ pump power $(\mathrm{kW})$

$\mathrm{H} \quad$ total dynamic head (m)

$\eta_{\mathrm{T}} \quad$ overall pump efficiency

Q total system flow rate $(1 / \mathrm{s})$

Table (1): Dimensions and prices of PVC pipes applied in the study.

\begin{tabular}{|c|c|c|c|c|}
\hline $\begin{array}{c}\text { Nominal } \\
\text { diameter (in) }\end{array}$ & $\begin{array}{c}\text { Outside } \\
\text { diameter } \\
(\mathrm{mm})\end{array}$ & $\begin{array}{c}\text { Wall } \\
\text { thickness } \\
(\mathrm{mm})\end{array}$ & $\begin{array}{c}\text { Inside } \\
\text { diameter } \\
(\mathrm{mm})\end{array}$ & Price $(\$ / \mathrm{m})$ \\
\hline $1-1 / 2^{\prime \prime}$ & 48.3 & 5.1 & 38.1 & 2.8 \\
\hline $2^{\prime \prime}$ & 60.3 & 5.5 & 49.3 & 4.0 \\
\hline $2-1 / 2^{\prime \prime}$ & 73.0 & 7.0 & 59.0 & 6.4 \\
\hline $3 "$ & 88.9 & 7.6 & 73.7 & 7.9 \\
\hline $3-1 / 2^{\prime \prime}$ & 101.6 & 8.1 & 85.4 & 11.4 \\
\hline $4 "$ & 114.3 & 8.6 & 97.2 & 17.1 \\
\hline $5 "$ & 141.3 & 9.5 & 122.3 & 21.9 \\
\hline $6 "$ & 168.3 & 11.0 & 146.3 & 33.1 \\
\hline $8^{\prime \prime}$ & 219.1 & 12.7 & 193.7 & 49.0 \\
\hline $10^{\prime \prime}$ & 273.1 & 15.1 & 242.9 & 67.0 \\
\hline $12 "$ & 323.9 & 17.4 & 289.0 & 95.2 \\
\hline
\end{tabular}


The capital cost of the pump $C C_{\text {pipe }}$ required to discharge the water with the proper pressure head to operate the system was calculated as follows:

$$
C_{P_{\text {ump }}}=P \times k W c
$$

Where $k W c$ is the pump unit power cost (L.E/Kw)

\section{Annual fixed costs:}

These costs involve pipes and the pump capital costs. The following equations were used to compute the annual fixed cost by the application of an amortization factor (James, 1988):

$$
\begin{gathered}
A F C=C R F_{1} \times C_{\text {Pipe }}+C R F_{2} x C C_{P_{\text {uump }}} \\
C R F=\frac{i r(1-i r)^{L F}}{(1-i r)^{L F}-1}
\end{gathered}
$$

Where:

$A F C$ annual fixed cost

$C R F_{1,2}$ capital recovery factor, for pipes and pump respectively.

$L F \quad$ estimated life (year)

ir annual interest rate (decimal)

The total annual energy cost of water supplied to the delivery is given as:

$$
A E C=P T_{i} C_{K W}
$$

Where:

$A E C$ annual energy cost (L.E/year)

$T_{i} \quad$ irrigation operating time (h/year)

$C_{K W} \quad$ cost of energy (L.E/ $\left.\mathrm{C}_{\mathrm{KW}}\right)$

\section{Annual total cost.}

Annual total cost (ATC) was estimated by the following equation:

$$
A T C=\frac{A E C+A F C}{A_{T}}
$$

Where:

$\mathrm{A}_{\mathrm{T}} \quad$ total area (fed.) 


\section{Algorithm and methods used \\ Linear programming model:}

The objective function and the associated constraints form the model which can be solved by means of appropriate program. For the herein study the solution was applied by Microsoft Excel workbook with solver application. Solver is capable to solve both linear and non linear models. Linear and integer problems use the Simplex method with bounds on variable, and the branch bound method.

\section{The basic inputs to the model are:}

- Total area $\left(\mathrm{A}_{\mathrm{T}}\right)$ and the dimensions of the field, $\mathrm{X}, ;(\mathrm{m})$ and $\mathrm{Y}(\mathrm{m})$.

- No. of nodes (n) and No. of sections (m) of the system.

- Length $\mathrm{L}(\mathrm{m}) ; \mathrm{m}$ and discharge $\mathrm{Q}(\mathrm{m}) ;(\mathrm{l} / \mathrm{s})$ along system sections.

- Elevation at each node $\Delta \mathrm{z}(\mathrm{n}) ;(\mathrm{m})$

- Distance between sprinklers, se; (m) and between laterals sl;(m).

- Seasonal operation time for irrigation $T_{i}$; (hour/year).

- Sprinkler operating pressure $\mathrm{hs} ;(\mathrm{m})$ and nominal flow rate $\mathrm{q}_{\mathrm{s}}$; $(1 / \mathrm{s})$

- The energy cost $C_{K W}$ (L.E/ $\left.\mathrm{C}_{\mathrm{KW}}\right)$

- The cost functions of diameter $\mathrm{C}_{1}$ and $\mathrm{C}_{2}$

- Efficiencies for the electric motor $\eta \mathrm{m}$; (dicemal) and pump $\eta p$; (dicemal)

- Estimated lives of PVC pipes $\mathrm{LF}_{\text {pipe }}$ and pump $\mathrm{LF}_{\text {pump }}$ and annual interest rate ir

- Cost of unit power $k W c$ (L.E/kwc)

\section{Pipe diameter based on water velocity:}

Many investigators applied water velocity method to design the water conveyance pipes ranged between $1-3 \mathrm{~m} / \mathrm{s}$ depending on pipe material. Applying the continuity module:

$$
Q=A \times V \rightarrow D=\sqrt{\frac{4 Q}{\pi V}}=18.8 \sqrt{\frac{Q}{V}}
$$

Where:

D diameter in ( $\mathrm{mm})$

Q discharge (1/s)

$\mathrm{V}$ water velocity $(\mathrm{m} / \mathrm{s})$ 


\section{Pipe diameter passed on friction head loss gradient:}

The pipes are commonly assumed to be hydraulically smooth and friction losses are often calculated using Hazien - Williames equation with $\mathrm{C}$ value of 150 as:

$$
\begin{gathered}
J=100 \frac{h f}{L}=1.21 \times 10^{12}\left(\frac{Q}{C}\right)^{1.852} D^{-4 . .87} \\
D=\left[\frac{1}{J} 1.21 \times 10^{12}\left(\frac{Q}{150}\right)^{1.852}\right]^{\frac{1}{4.87}}
\end{gathered}
$$

D inner pipe diameter $\mathrm{mm}$

$\mathrm{J}$ friction factor $\mathrm{m} / 100 \mathrm{~m}$

Q passing discharge $1 / \mathrm{s}$

\section{RESSULTS AND DISCUSSION}

The main objective of the study is to minimize the total annual cost of sprinkler irrigation conveyance water pip network. An optimum pipe sizes for the network was proposed to get minimum summation of pipe and pump fixed cost and energy cost by linear programming model. The model results were compared with two other methods for the same minimum values. Water limited velocity from $1 \mathrm{~m} / \mathrm{s}$ to $3 \mathrm{~m} / \mathrm{s}$ was applied. The results given enable an examination of the influence of water velocity inside the pipe sections and head loss gradient values on cost analyses of sprinkler irrigation pipe networks or to find an optimum solution among various operating conditions. The utility and capability of the model and the effect of the design variables on the least cost of the system are best demonstrated by numerical case study.

\section{Case study and analysis of model:}

Sprinkler irrigation system, Fig. (2) designed for about 110 faddan cover 10 fields each with two submains and two hand moved sprinkler laterals. The system comprises junctions or nodes and pipe sections between adjacent nodes. On the system layout shown in Fig. (2), there are i nodes and $\mathrm{j}$ pipe sections $\mathrm{i}=1,2,3 \mathrm{n}=13$, each pipe section is assigned the same number as the node downstream $\mathrm{j}=1,2,3 \ldots \mathrm{m}=13$. The pressure head $\mathrm{Hu}(\mathrm{i})$ required at the inlet to lateral is determined at node 7 and 13 as the furthest lateral inlet nodes. 


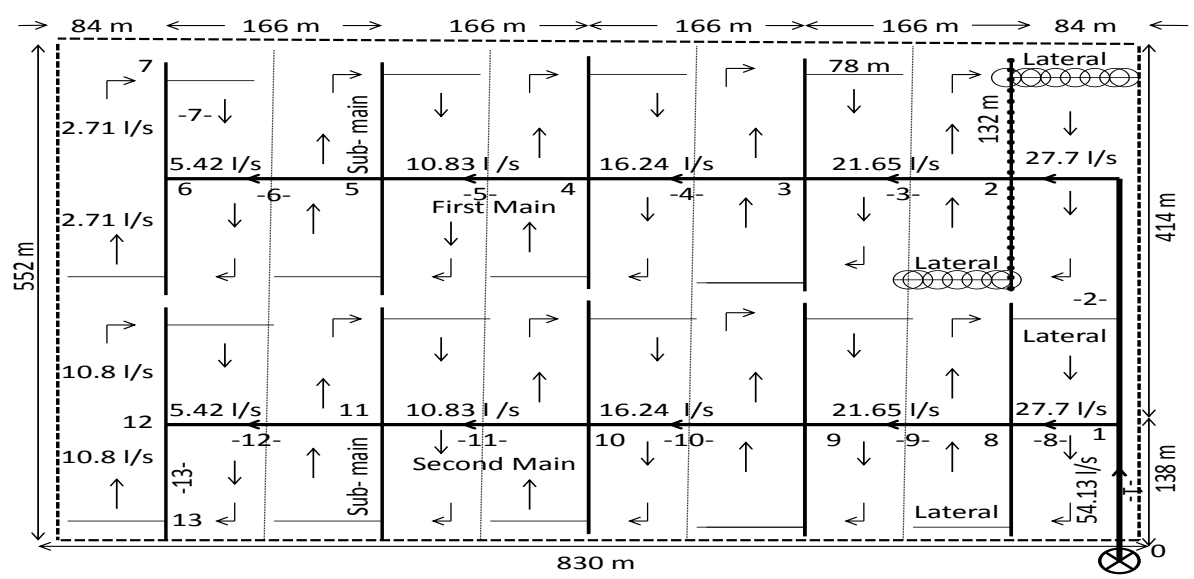

Fig. (2 ): Plan of the case study area, nodes, discharges and lengths of the different pipe sections on the system.

The constraints of the decision variable at each pipe sections for the first mainline (water pass from 0-7) and the second mainline (water pass 0-13) are given in Fig. (3). The constraints of water limits and non-negativity variable were also given. The available pressure head $H O$ at the pump (or the total dynamic head $T D H$ ) is computed by summing the required pressure at the lateral inlet $H u(7)$ and friction losses along the longest branch on the net work $H f(7)$, elevation difference between the pump and highest or lowest point on the network, pump net positive suction head NPSH (assumed as $5 \mathrm{~m}$ ), pump lift and adding extra $20 \%$ of the friction loss as minor losses along the network. The working pressure head of sprinkler is 3 Bar. Friction loss by 2" PVC lateral $84 \mathrm{~m}$ length was $4.5 \mathrm{~m}$, lateral delivers $2.71 \mathrm{l} / \mathrm{s}$ by means of 7 sprinklers placed $7 \times 7 \mathrm{~m}$. sprinkler discharge about $1.4 \mathrm{~m}^{3} / \mathrm{h}$. Nodes No., section No., lengths and discharges are given in Tab. (2)

\section{Linear programming model results:}

According to the linear programming procedure, the objective function is to find the least annual total cost of operating the regional conveyance piping system. The results of the linear programming model minimum total annual cost was 1135 \$/season.fed. in case of continues diameter increased to 1187 \$/season.fed. in case of discrete diameters. The complete results presented in Tab.(3). Tab. (4) showed the results of the linear programming model in case of continues diameter, that means the 
program used the exact diameter value as calculated and consider the price according to the power function and $c_{1}, c_{2}$ used to calculate the unit length of specific diameter. The other case, discrete diameter means; the use of available diameter in market only. According to this process the total annual cost increased by $4,5 \%$. Therefore, availability of diameters of small increments will produce cheaper designs.

Tab: (2): Node and section numbers along the system with related length and discharge

\begin{tabular}{|c|c|c|c|}
\hline Sections between nodes & Section No. & $\begin{array}{c}\text { Length } \\
(\mathrm{m})\end{array}$ & Discharge( 1/s) \\
\hline $0-1$ & $-1-$ & 138 & 54.13 \\
\hline $1-2$ & $-2-$ & 360 & 27.70 \\
\hline $2-3$ & $-3-$ & 166 & 21.65 \\
\hline $3-4$ & $-4-$ & 166 & 12.24 \\
\hline $4-5$ & $-5-$ & 166 & 10.83 \\
\hline $5-6$ & $-6-$ & 166 & 5.42 \\
\hline $6-7$ & $-7-$ & 132 & 2.71 \\
\hline $1-8$ & $-8-$ & 84 & 27.70 \\
\hline $8-9$ & $-9-$ & 166 & 21.65 \\
\hline $9-10$ & $-10-$ & 166 & 12.24 \\
\hline $10-11$ & $-11-$ & 166 & 10.83 \\
\hline $11-12$ & $-12-$ & 166 & 5.42 \\
\hline $12-13$ & $-13-$ & 132 & 2.71 \\
\hline
\end{tabular}

For the first main line: pass $(0-7)$

$$
\begin{gathered}
H o \pm Z o-h f(-1-) \geq H u(1) \pm Z(1) \\
H o \pm Z o-h f(-1-)-h f(-2-) \geq H u(2) \pm Z(2) \\
H o \pm Z o-h f(-1-)-h f(-2-)-h f(-3-) \geq H u(3) \pm Z(3) \\
H o \pm Z o-h f(-1-)-h f(-2-)-h f(-3-)-h f(-4-) \\
\geq H u(4) \pm Z(4) \\
H o \pm Z o-h f(-1-)-h f(-2-)-h f(-3-)-h f(-4-)-h f(-5-) \\
\geq H u(5) \pm Z(5) \\
H o \pm Z o-h f(-1-)-h f(-2-)-h f(-3-)-h f(-4-)-h f(-5-) \\
-h f(-6-) \geq H u(6) \pm Z(6) \\
H o \pm Z o-h f(-1-)-h f(-2-)-h f(-3-)-h f(-4-)-h f(-5-) \\
-h f(-6-)-h f(-7) \geq H u(7) \pm Z(7)
\end{gathered}
$$


For the second main line: pass $(0-13)$

$$
\begin{gathered}
H o \pm Z 0-h f(-1-)-h f(-8-) \geq H u(8) \pm Z(8) \\
H o \pm Z 0-h f(-1-)-h f(-8-)-h f(-9-) \geq H u(9) \pm Z(9) \\
H 0 \pm Z 0-h f(-1-)-h f(-8-)-h f(-9-)-h f(-10-) \\
\geq H u(10) \pm Z(10) \\
H o \pm Z 0-h f(-1-)-h f(-8-)-h f(-9-)-h f(-10-) \\
-h f(-11-) \geq H u(11) \pm Z(11) \\
H o \pm Z o-h f(-1-)-h f(-8-)-h f(-9-)-h f(-10-) \\
-h f(-11-)-h f(-12-) \geq H u(12) \pm Z(12) \\
H 0 \pm Z o-h f(-1-)-h f(-8-)-h f(-9-)-h f(-10-) \\
-h f(-11-)-h f(-12-)-h f(-13-) \\
\geq H u(13) \pm Z(13) \\
1 m / s \leq\{V(-1-) \ldots . ., V(-12-)\} \leq 2 m / s \\
\{D(-1-) \ldots . ., D(-12-)\} \geq 0
\end{gathered}
$$

\begin{tabular}{|c|c|c|c|c|c|c|c|c|c|c|}
\hline \multirow[b]{2}{*}{$\begin{array}{l}\dot{0} \\
\dot{z} \\
\dot{0} \\
\dot{0} \\
\dot{n}\end{array}$} & \multirow[b]{2}{*}{ 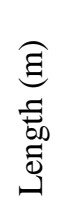 } & \multirow[b]{2}{*}{ 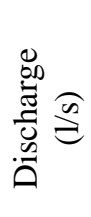 } & \multicolumn{4}{|c|}{ Continuous diameter } & \multicolumn{4}{|c|}{ Discrete diameter } \\
\hline & & & $\begin{array}{l}\stackrel{\bar{\Xi}}{\Xi} \Xi \\
\stackrel{\Xi}{\Xi} \Xi\end{array}$ & 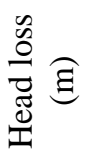 & 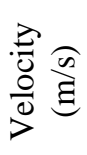 & 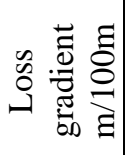 & 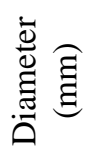 & 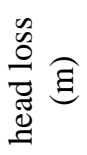 & 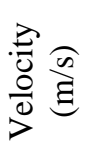 & 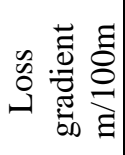 \\
\hline$(-1-)$ & 138 & 54.13 & 194.3 & 1.83 & 1.83 & 1.33 & 242.9 & 0.62 & 1.17 & 0.45 \\
\hline$(-2-)$ & 360 & 27.70 & 137.2 & 7.19 & 1.83 & 2.00 & 146.3 & 5.25 & 1.61 & 1.46 \\
\hline$(-3-)$ & 166 & 21.65 & 128.4 & 3.03 & 1.67 & 1.82 & 146.3 & 1.60 & 1.29 & 0.96 \\
\hline$(-4-)$ & 166 & 16.24 & 118.2 & 2.66 & 1.48 & 1.60 & 122.3 & 2.26 & 1.38 & 1.36 \\
\hline$(-5-)$ & 166 & 10.83 & 105.3 & 2.21 & 1.24 & 1.33 & 122.3 & 1.06 & 0.92 & 0.64 \\
\hline$(-6-)$ & 166 & 5.42 & 81.0 & 2.18 & 1.05 & 1.32 & 85.4 & 1.69 & 0.94 & 1.02 \\
\hline$(-7-)$ & 132 & 2.71 & 48.6 & 5.79 & 1.46 & 4.39 & 49.3 & 5.45 & 1.42 & 4.13 \\
\hline$(-8-)$ & 84 & 27.07 & 133.8 & 1.89 & 1.92 & 2.25 & 146.3 & 1.23 & 1.61 & 1.46 \\
\hline$(-9-)$ & 166 & 21.65 & 120.1 & 4.20 & 1.91 & 2.53 & 122.3 & 3.84 & 1.84 & 2.32 \\
\hline$(-10-)$ & 166 & 16.24 & 110.7 & 3.66 & 1.69 & 2.20 & 122.3 & 2.26 & 1.38 & 1.36 \\
\hline$(-11-)$ & 166 & 10.83 & 98.5 & 3.05 & 1.42 & 1.84 & 122.3 & 1.06 & 0.92 & 0.64 \\
\hline$(-12-)$ & 166 & 5.42 & 81.0 & 2.18 & 1.05 & 1.32 & 85.4 & 1.69 & 0.94 & 1.02 \\
\hline$(-13-)$ & 132 & 2.71 & 45.4 & 8.07 & 1.67 & 6.11 & 49.3 & 5.45 & 1.42 & 4.13 \\
\hline
\end{tabular}

Fig. (3). The Constrains to solve the decision variable $h f$ along the different pipe sections along the two main lines

Tab.(3): Linear programming results for continuous versus discrete diameter calculations 
Tab.(4): Hydraulic and finance results of the linear programming model

\begin{tabular}{|l|c|c|}
\hline \multicolumn{1}{|c|}{ Item of } & Continuous diameter & Discrete diameter \\
\hline Total flow rate $(\mathrm{l} / \mathrm{s})$ & 54.13 & 54.13 \\
\hline Total friction loss $(\mathrm{m})$ & 24.88 & 17.39 \\
\hline Total dynamic head $(\mathrm{m})$ & 72.36 & 64.02 \\
\hline Pump power $(\mathrm{Kw})$ & 66.50 & 58.84 \\
\hline Pump capital cost (L.E) & 66503 & 58836 \\
\hline Pipes capital cost (L.E) & 459769 & 542215 \\
\hline Season energy cost (L.E./season) & 47882 & 42362 \\
\hline Total fixed cost (L.E) & 75984 & 87112 \\
\hline Total cost $(\$ . /$ season. fed) & 1135 & 1187 \\
\hline Flow average velocity $(\mathrm{m} / \mathrm{s})$ & 1.55 & 1.30 \\
\hline Average friction factor $(\mathrm{m} / 100 \mathrm{~m})$ & 2.31 & 1.61 \\
\hline
\end{tabular}

\section{Limited velocity procedure results:}

The water velocity ranged between $1 \mathrm{~m} / \mathrm{s}$ to $3 \mathrm{~m} / \mathrm{s}$ is applied at each pipe section from -1- to -13- to get the pipe size. Accordingly, the total annual cost and the parameters related were determined and given in Tab. (5). The minimum total annual cost is found at $1.5 \mathrm{~m} / \mathrm{s}$ related to 2.25 $\mathrm{m} / 100 \mathrm{~m}$, as 1184 \$/year.

Tab. (5): Results of applying velocity limit method to get minimum total annual cost.

\begin{tabular}{|c|c|c|c|c|c|c|c|c|}
\hline $\begin{array}{c}\text { Velocity } \\
\mathrm{m} / \mathrm{s}\end{array}$ & $\begin{array}{c}\text { Total } \\
\text { dynamic } \\
\text { head (m) }\end{array}$ & $\begin{array}{c}\text { Pump } \\
\text { power } \\
\text { (K/w) }\end{array}$ & $\begin{array}{c}\text { Pump } \\
\text { capital } \\
\text { cost } \\
\text { (L.E.) }\end{array}$ & $\begin{array}{c}\text { Pipes } \\
\text { capital } \\
\text { cost } \\
\text { (L.E.) }\end{array}$ & $\begin{array}{c}\text { Annual } \\
\text { operating } \\
\text { cost } \\
\text { (L.E./year) }\end{array}$ & $\begin{array}{c}\text { Annual } \\
\text { fixed cost } \\
\text { (L.E./year) }\end{array}$ & $\begin{array}{c}\text { Annual } \\
\text { total cost } \\
\text { (L.E./year) }\end{array}$ & $\begin{array}{c}\text { Average } \\
\text { friction } \\
\text { factor } \\
\text { (m/100m) }\end{array}$ \\
\hline 1.0 & 53.9 & 49.5 & 49537 & 695388 & 35666 & 108416 & 1321 & 0.84 \\
\hline 1.5 & 73.1 & 67.2 & 67179 & 491687 & 48369 & 80757 & 1184 & 2.25 \\
\hline 2.0 & 104.1 & 95.7 & 95713 & 381468 & 68914 & 68212 & 1257 & 4.54 \\
\hline 2.5 & 148.6 & 136.6 & 136604 & 311057 & 98355 & 63088 & 1480 & 7.81 \\
\hline 3.0 & 207.9 & 191.1 & 191117 & 261584 & 137604 & 62774 & 1837 & 12.18 \\
\hline
\end{tabular}

\section{Unit head loss gradient method results:}

Head loss gradient was applied; ranged between 1 to $7 \mathrm{~m} / 100 \mathrm{~m}$; to get the sections diameter. The same as water limited velocity, 8 parameters were determined to get the total annual cost as shown in Tab.(6). Minimum value is $1186 \$$ /year.fed. given at $2 \mathrm{~m} / 100 \mathrm{~m}$ friction factor. The minimum total annual cost was at velocity $1.54 \mathrm{~m} / \mathrm{s}$. 
Fig. (6): Results of applying friction factor method to get minimum total annual cost.

\begin{tabular}{|r|c|c|r|r|r|r|r|c|}
\hline $\begin{array}{c}\text { Average } \\
\text { friction } \\
\text { factor } \\
\mathrm{m} / 100 \mathrm{~m}\end{array}$ & $\begin{array}{c}\text { Annual } \\
\text { total } \\
\text { cost } \\
\text { L.E./y }\end{array}$ & $\begin{array}{c}\text { Annual } \\
\text { fixed } \\
\text { cost } \\
\text { L.E./y }\end{array}$ & $\begin{array}{c}\text { Annual } \\
\text { operating } \\
\text { cost } \\
\text { L.E./y }\end{array}$ & $\begin{array}{c}\text { Pipes } \\
\text { capital } \\
\text { cost } \\
\text { (L.E.) }\end{array}$ & $\begin{array}{c}\text { Pump } \\
\text { capital } \\
\text { cost } \\
\text { L.E. }\end{array}$ & $\begin{array}{c}\text { Pump } \\
\text { power } \\
\text { Kw }\end{array}$ & $\begin{array}{c}\text { Total } \\
\text { dynamic } \\
\text { head } \\
\mathrm{m}\end{array}$ & $\begin{array}{c}\text { Friction } \\
\text { Factor } \\
\mathrm{m} / 100 \\
\mathrm{~m}\end{array}$ \\
\hline 1.16 & 1255 & 98456 & 38399 & 624257 & 53331 & 53.3 & 58.0 & 1 \\
\hline 1.54 & 1186 & 80648 & 48674 & 490580 & 67603 & 67.6 & 73.6 & 2 \\
\hline 1.82 & 1208 & 72820 & 58949 & 424867 & 81874 & 81.9 & 89.1 & 3 \\
\hline 2.05 & 1262 & 68492 & 69224 & 382997 & 96145 & 96.1 & 104.6 & 4 \\
\hline 2.25 & 1333 & 65902 & 79500 & 352967 & 110416 & 110.4 & 120.1 & 5 \\
\hline 2.42 & 1413 & 64334 & 89775 & 329897 & 124688 & 124.7 & 135.7 & 6 \\
\hline 2.58 & 1499 & 63432 & 100050 & 311357 & 138959 & 139.0 & 151.2 & 7 \\
\hline
\end{tabular}

Influence of water velocity and head loss gradient as design parameters to get optimum diameters of the sprinkler irrigation conveyance water system that leads to minimum total annual cost was studied and presented in Fig. (4) and Fig. (5). As shown in both figures, annual fixed cost steadily decreased as water velocity and head loss gradient values increased, while annual energy cost increased as water velocity and head loss gradient increased. Annual total cost which equal the sum of the fixed and energy costs decreases to a minimum and then steadily increases. The recommended water velocity or head loss gradient values are the corresponding to the almost lowest total cost. The trend of these results is the same as given by many studies to get the optimum pipe diameter directly in design optimum single pipe diameter.

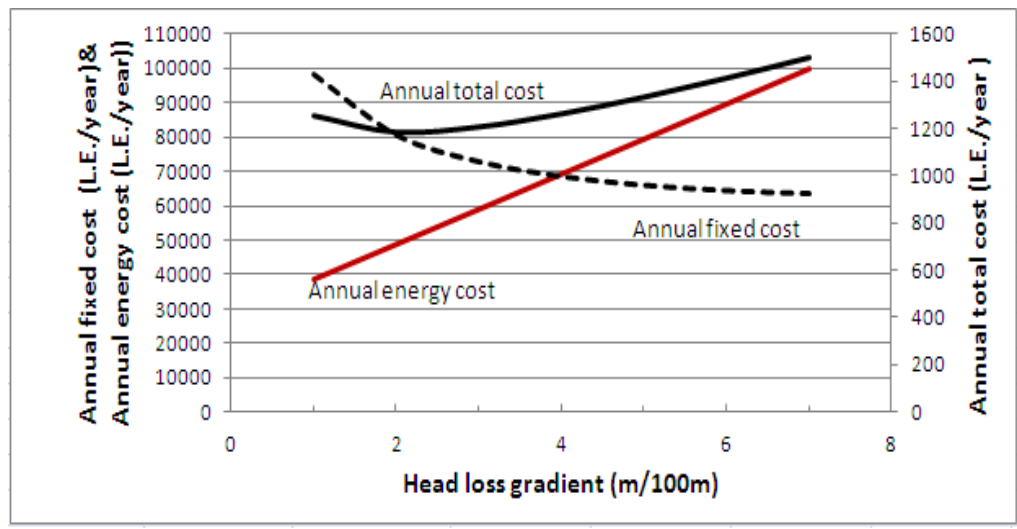

Fig. (4): Relationships between annual total cost, annual fixed cost and annual energy cost at different head loss gradient values 


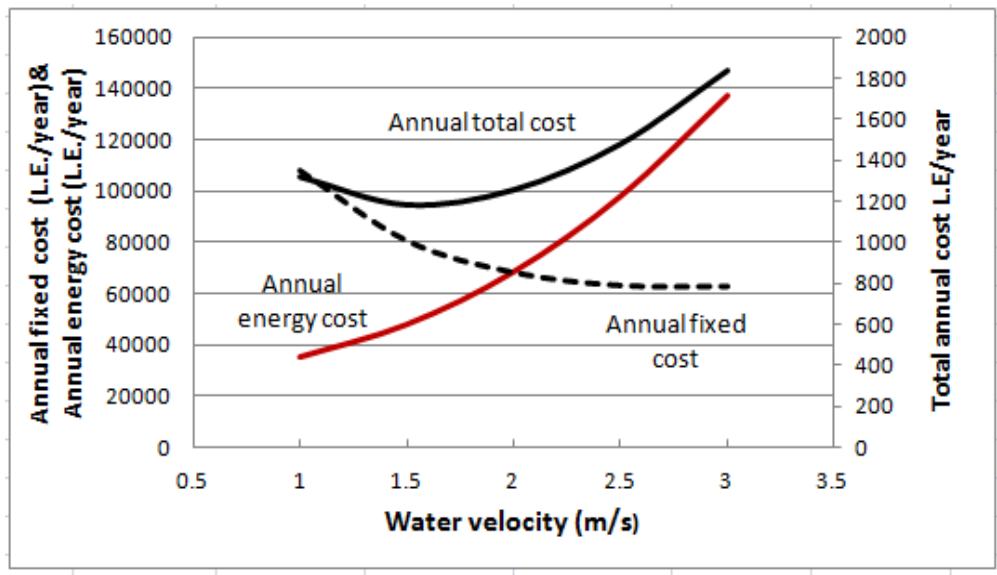

Fig. (5): Relationships between annual total cost, annual fixed cost and annual energy cost at different water velocity values

\section{Verifying the linear programming model:}

The linear programming design model for the minimum total annual cost of sprinkler irrigation system was verified by comparing its results by the other methods applied as shown in Tab. (7). Initially, the total annual cost estimated by the linear programming method is the lowest among the all methods in both cases of continues or discrete diameters. It is logic that the total annual cost based on discrete diameter is higher than given by the continuous diameters. The differences were $4.5 \%, 5.9 \%$ and $1.4 \%$ for linear programming, velocity and head loss gradient methods respectively. In case of using discrete diameters, the results indicated that water velocity, head loss gradient are higher than the linear programming model results of total annual cost by $4.2 \%$ and $4.4 \%$ respectively. In case of using the continuous diameter, the velocity method and head loss gradient results of total annual cost are higher than the linear programming results by $4.2 \%$ and $4.4 \%$ respectively.

According to these results, it could be considered that the linear programming model is accurate and precise to get the optimum diameters leads to minimum total annual cost of water conveying system of regional sprinkler irrigation system. Otherwise it is recommended to use the average velocity value as 1.54 to get the optimum system diameters for 
the least cost, or head loss gradient value as $2.3 \mathrm{~m} / 100 \mathrm{~m}$ as design factor for minimum cost.

Tab.(7): Comparing the linear programming method results with the other two methods

\begin{tabular}{|c|c|c|c|c|c|c|c|c|}
\hline \multirow{2}{*}{ 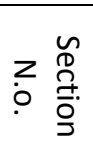 } & \multirow{2}{*}{ 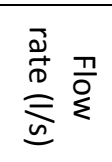 } & \multirow{2}{*}{ 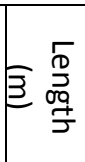 } & \multicolumn{2}{|c|}{$\begin{array}{c}\text { Linear } \\
\text { programming }\end{array}$} & \multicolumn{2}{|c|}{$\begin{array}{l}\text { Velocity } \\
\text { method }\end{array}$} & \multicolumn{2}{|c|}{$\begin{array}{c}\text { Head loss } \\
\text { gradient method }\end{array}$} \\
\hline & & & Cont. & Disc. & Cont. & Disc. & Cont. & Disc. \\
\hline$(-1-)$ & 54.13 & 132 & 194.3 & 242.9 & 214.4 & 242.9 & 178.5 & 193.7 \\
\hline$(-2-)$ & 27.07 & 360 & 137.2 & 146.3 & 151.6 & 193 & 137.1 & 46.3 \\
\hline$(-3-)$ & 21.65 & 166 & 28.4 & 146.3 & 135.6 & & 126.0 & 146.3 \\
\hline$(-4-)$ & 16.24 & 166 & 18.2 & 122.3 & 117.4 & & 112.9 & 122.3 \\
\hline$(-5-)$ & 10.83 & 166 & 105.3 & 122.3 & 95.9 & & 96.8 & 97.2 \\
\hline$(-6-)$ & 5.41 & 166 & 1.0 & 85.4 & 67.8 & & 74.4 & 5.4 \\
\hline$(-7-)$ & 2.71 & 132 & 48.6 & 49.3 & 47.9 & & 57.1 & 9.0 \\
\hline$(-8-)$ & 27.07 & 84 & 133.8 & 146.3 & 151.5 & 193.7 & 137.1 & 146.3 \\
\hline$(-9-)$ & 21.65 & 166 & 20.1 & 122 & 135.5 & & 126.0 & 146.3 \\
\hline$(-10-)$ & 16.24 & 166 & 110.7 & 122 & 117.4 & 12 & 112.9 & 122.3 \\
\hline$(-11-)$ & 10.83 & 166 & 98.5 & 122.3 & 95.8 & & 96.8 & 97.2 \\
\hline$(-12-)$ & 5.41 & 166 & 81.0 & 85.4 & 67.8 & .7 & 74.4 & 85.4 \\
\hline$(-13-)$ & 2.71 & 138 & 45.44 & 49.25 & 47.92 & 49.25 & 57.13 & 59.00 \\
\hline \multicolumn{3}{|c|}{ T.D.H $(\mathrm{m})$} & 72.36 & 64.02 & 73.10 & 64. & 73.56 & 64.30 \\
\hline \multicolumn{3}{|c|}{ PUMP. P. (KW) } & 66.50 & 58.84 & 67.18 & 58.90 & 67.60 & 59.09 \\
\hline \multicolumn{3}{|c|}{ PUMPC.C. (L.E) } & 66503 & 58836 & 67179 & 58900 & 67603 & 59095 \\
\hline \multicolumn{3}{|c|}{ PIPES C.C (L.E) } & 769 & 542215 & 491687 & 5914 & 490580 & 134 \\
\hline \multicolumn{3}{|c|}{ Y. energy cost (L.E./Y) } & 47882 & 42362 & 48369 & 424 & 48674 & 42548 \\
\hline \multicolumn{3}{|c|}{ Total capital cost (L.E) } & 75984 & 87112 & 80757 & 94350 & 80648 & 88601 \\
\hline \multicolumn{3}{|c|}{ Annual T. C. (L.E/Y) } & 1135 & 1187 & 1184 & 1254 & 1186 & 1202 \\
\hline \multicolumn{3}{|c|}{ System aver. $\mathrm{V}(\mathrm{m} / \mathrm{s})$} & 1.55 & 1.3 & 1.5 & 1.4 & 1.5 & 1.0 \\
\hline \multicolumn{3}{|c|}{ Aver. Fri. F.(m/100m) } & 2.00 & 1.4 & 2.3 & 1.4 & 2.0 & 1.4 \\
\hline
\end{tabular}

\section{Checking head at the terminal nodes.}

In order to insure the arrival of water with enough pressure at the last sprinkler, calculations are made to check head at the terminal nods No 7 and No.13, which are lateral inlets. In the study the pressure at these nodes should not be less than $36 \mathrm{~m}$. From the system inlet to the far point on the submain the pressure head and friction loss along each section are calculated using the friction formula applied by the study with the same $\mathrm{C}$ value (150). The friction loss includes $20 \%$ excess as minor losses. The 
pressure head, friction value, pipe diameter and flow rate at the system section are given in Fig.(6). According to this process the pressure head at the node No. 7 and node No. 13 was found as $36 \mathrm{~m}$. This confirms the applicability and accuracy of the linear programming model.

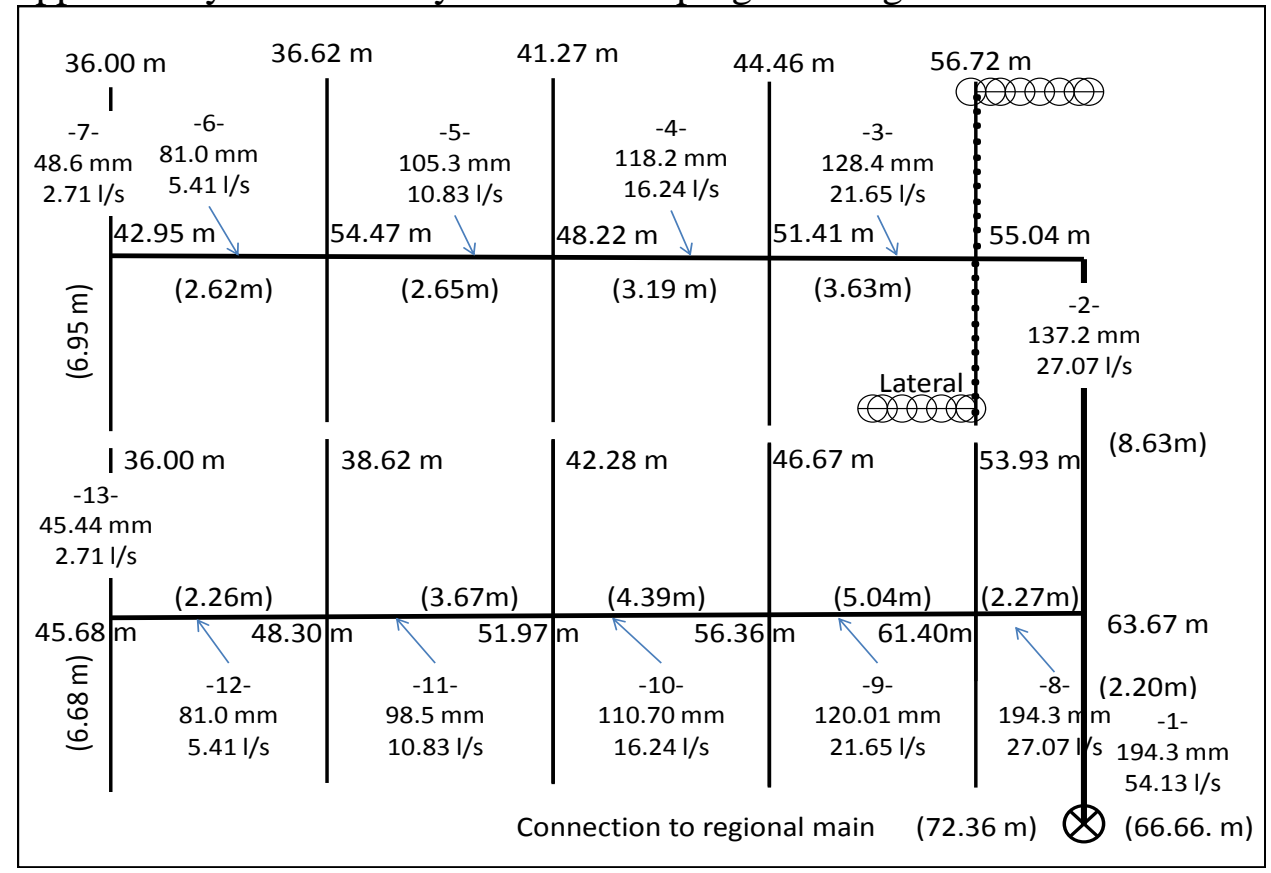

Fig.(6): Pressure distribution on the system to check the pressure at the terminal nodes

\section{CONCLUSIONS}

The objective of the study was to develop linear programming design model for water conveying main lines for regional sprinkler irrigation system. The objective function is based on minimizing the total annual cost. The dilemma is to balance between the total fixed cost of pipes and pump, and the annual operating cost of energy and get the minimum total annual cost. Other two methods for design have the same target are used, presented and compared with the linear programming model results. The comparison of results indicated the validity of the linear programming model to design the system for minimum total annual cost and could be recommended to apply such model to design pressurized irrigation system. The advantages of using linear programming are many. In addition to get the minimum total annual cost directly in one run, easy to 
format the constraints, easy to solve by computer by applying the application of solver on Microsoft Excel worksheet. The results of comparing the different methods indicated that the value of average velocity as $1.5 \mathrm{~m} / \mathrm{s}$ as design parameter could result in minimum cost or head loss gradient value as $2.3 \mathrm{~m} / 100 \mathrm{~m}$ as design factor for minimum cost. Choice of candidate diameters depends upon the manufacturer's product. Availability of diameters of small increments will produce less expensive designs.

\section{REFERENCES}

Bratls VF, Kelly SF, Shayya WH, Segerling LJ. 1993. Finite element analysis of micro irrigation hydraulics using a virtual emitter system. Transactions ASAE 36(3): 717-725.

Bratls VF, Segerlind LJ. 1985. Finite element analysis of drip irrigation submain units. Transactions ASAE 28(3): 809-814.

Ismail, S. M., EL- Ashry S. R.; Sharaf, G. A. and M. N. El- Nesr, 2001, Computer aided design of trickle irrigation system, Misr Journal of Agric. Eng., 18 (2):243-260.

Kang V, Nishiyama S. 1996a. Analysis and design of micro irrigation laterals. Journal of Irrigation and Drainage Engineering 122(2): 7582.

Keller J, Bliesner RD. 1990. Sprinkle and Trickle Irrigation. Van Nostrand Reinhold, Chapman and Hall: New York.

Keller J. 1975. Economic pipe selection chart. In Proceedings, ASCE Irrigation and Drainage Division Special Conference, 13-15 Aug.1968, Utah State University, Logan, Utah.

Labye Y, Olson MA, Galand A, Tsourtis N. 1988. Design and optimization of distribution network. Irrigation and Drainage Paper No. 44. FAO: Rome.

Planells P, Ortega JF, Tarjuelo JM. 2007. Optimization of irrigation water distribution networks, layout included. Agricultural Water Management 88: 110-118. 
Sharaf, G. A.. 1996. Optimal design of trickle irrigation submain-unit. Misr Journal of Agric. Eng., 13 (3): 501 - 516.

Theocharis M, Tzimopoulos C, Yannopoulos S, Sakellariou- Makrantonaki M. 2006. Design of optimal irrigation networks. Irrigation and Drainage 55: 21-22.

Valiantzas JD. 2003a. Inlet pressure, energy cost and economic design of tapered irrigation submains. Journal of Irrigation and Drainage Engineering ASCE 129(2): 100-107.

\section{الملخص العربى}

\section{تصميم نظام أنابيب شبكة المياه للري بالرش بأقل تكلقة}

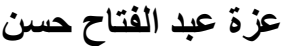

اجريت هذه الدر اسة لتقدير اقل تكاليف سنوية كلية لخطوط نقل مياه لشبكة رى بالرش تعاونيه. وقد تم تطبيق البرمجة الخطية لتقدير اقطار الانابيب المختلفة المناسبة و المؤدية الى أقل تكاليف

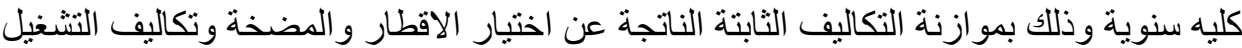

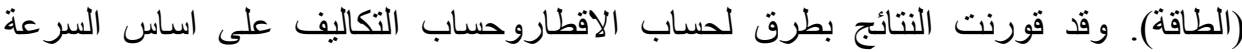

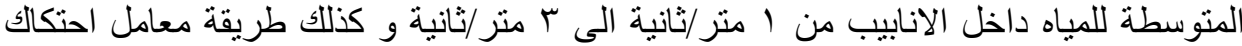

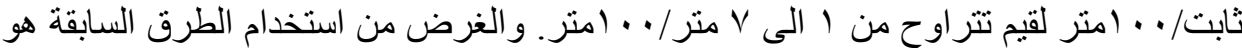

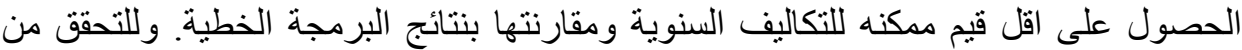

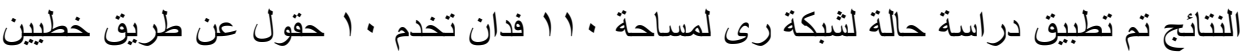

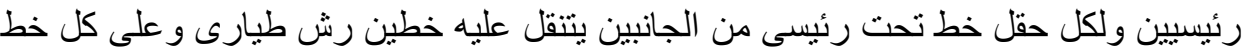

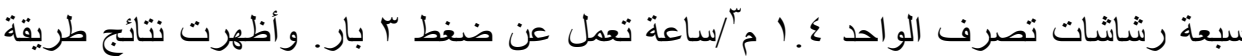

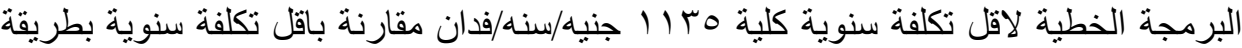

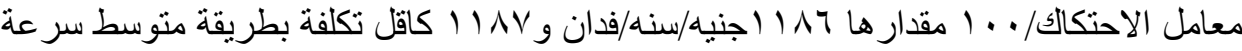
المياه داخل الانابيب و القيم السابقة بناء على الاقطار الحسابية واستخدام دالة القطر لحساب تكلفة القابة وحدة الطول. وتقارب نتائج الطرق المستخدمة بطريقة البرمجة الخطية يفيد بصلاحيتها ودقتها لإنها

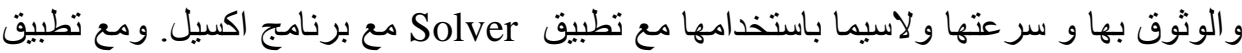

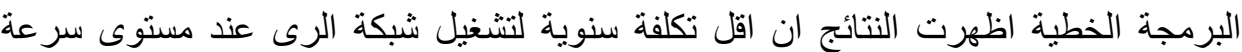

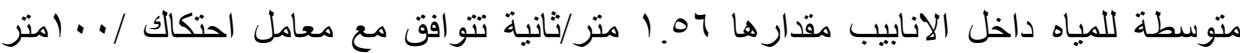

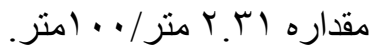

باحث اول بمعهد بحوث الهندة الزراعية ـ محطة اختبار الجرارات ـ الصباحية ـ الأسكندرية ـ مركز

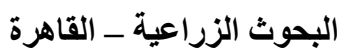


وتقاربت نتائج الطرق الاخرى مع طريقة البرمجة الخطية فمع تطبيق طريقة السر عة المنوسطة

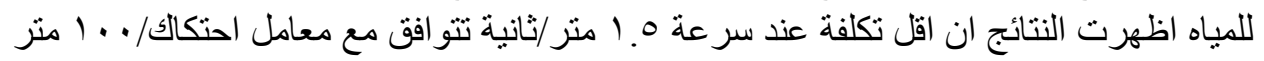

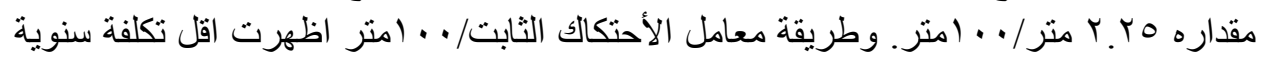

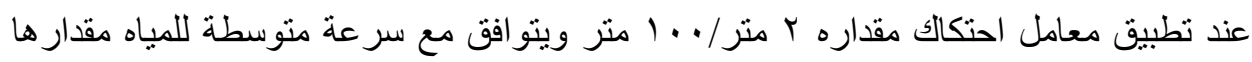

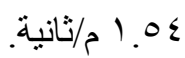

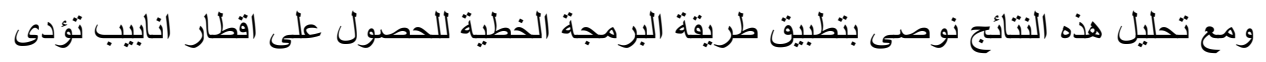

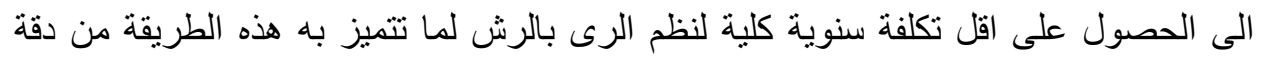
وسر عة مع تطبيقات الحاسب الالى المتاحة لبرنامج اكسيل (Solver).

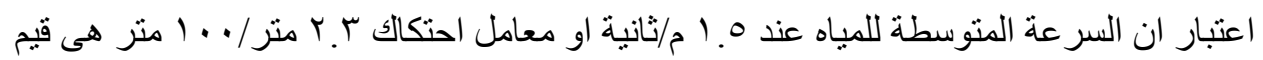

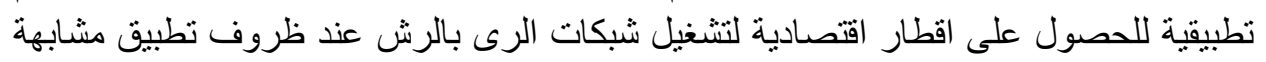
لحالة الدر اسةالتى تم على اساسها الحصول على لـى هذه النتائج. 